\title{
An Evaluation of a Research Experience for Teachers in Nanotechnology
}

\author{
Justin L Hess ${ }^{1}$, Anthony Chase ${ }^{1}$, Dan Minner ${ }^{2}$, Maher Rizkalla ${ }^{2,3}$, and Mangilal Agarwal2,4,* \\ ${ }^{1}$ STEM Education Innovation and Research Institute (SEIRI); ${ }^{2}$ Integrated Nanosystems Development Institute (INDI); \\ ${ }^{3}$ Department of Electrical and Computer Engineering; ${ }^{4}$ Department of Mechanical Engineering \\ Indiana University-Purdue University Indianapolis \\ *Corresponding Author: agarwal@iupui.edu
}

\begin{abstract}
This study involves the evaluation of the second implementation of a Research Experiences for Teacher Advancement In Nanotechnology (RETAIN) program offered at Indiana University-Purdue University Indianapolis (IUPUI). RETAIN represents a professional development model for providing high school teachers with laboratory research experiences in nanoscience and related content areas. In this intensive summer program, teachers spend six weeks conducting nanotechnology-related research in an IUPUI lab. As part of the RETAIN program, teachers complete six credit hours of coursework, wherein they translate their research experiences into the design of classroom modules. Teachers are expected to then implement their modules within their own classrooms during the subsequent academic year. This evaluation focuses on teachers' experiences in IUPUI labs during the summer of 2016, along with three teachers' implementation of nanotechnology labs within their courses during the 2016-2017 school year. To evaluate RETAIN, we explored teacher satisfaction, changes in teachers' content knowledge and nanotechnology perceptions, as well as changes in teachers' epistemological beliefs. Further, we explored the impact of the three teachers' module integration on their students' STEM attitudes and nanotechnology perceptions. The findings indicated that teachers were generally satisfied with the research and course experiences. Further, as a result of RETAIN participation, teachers showed increased nanotechnology content knowledge and knowledge of nanotechnology-related careers. Lastly, three teachers' integration of nanotechnology modules indicated that their students had significantly improved perceptions of nanotechnology's potential coupled with more knowledge of nanotechnology-related careers. The paper concludes with considerations of the quantitative findings in light of teachers' written reflections and author observations of teacher module integration in their classrooms.
\end{abstract}

Keywords-Nanotechnology; Evaluation; Teacher Training

\section{INTRODUCTION}

In recent years, national initiatives across the United States have supported the rapid advancement of nanotechnology research and development. For example, in 2000, President Clinton approved \$500 million for the founding of the National Nanotechnology Initiative (NNI), an inter-agency initiative that fostered partnerships between the National Science Foundation, the Department of Defense, the Department of Engineering, and several other federal agencies [1]. Nearly 20 years later, cumulative support for NNI has totaled approximately \$24 billion [2] which has contributed to more than $\$ 500$ billion in revenues generated from "nanotechnologyenabled" products in the United States alone [3]. NNI's 2016 strategic plan promoted four broad goals, including to:

Goal 1. Advance a world-class nanotechnology research and development program

Goal 2. Foster the transfer of new technologies into products for commercial and public benefit

Goal 3. Develop and sustain educational resources, a skilled workforce, and a dynamic infrastructure and toolset to advance nanotechnology

Goal 4. Support responsible development of nanotechnology

In alignment with these NNI goals, across the United States instructors have begun developing strategies for integrating nanotechnology into pre-college science, technology, engineering, and mathematics (STEM) curricula. For example, the Cornell NanoScale Science and Technology Facility has partnered with the National Nanotechnology Infrastructure Network in the design, development, and distribution of a magazine, Nanooze, that presents nanotechnology in an accessible and engaging manner for K-12 students. As one example, the "Energy Issue" elucidates concepts such as solar power, graphene, and batteries [4]. Many other related nanotechnology resources are accessible online [5]. This study builds on the year 1 evaluation of an NSF-funded Research for Experiences program hosted at IUPUI to explore the program impact on year 2 participants [6].

\section{STUDY OVERVIEW}

This study involves the evaluation of a professional development program offered at IUPUI called Research Experiences for Teacher Advancement In Nanotechnology (RETAIN). RETAIN provides high school teachers from urban school districts with research experiences and course activities designed to increase their understanding of the potential of nanotechnology, enhance their knowledge of nanotechnology concepts, and promote their ability to implement nanotechnology into their classroom in a manner that increases students' STEM disciplinary and career interests. As part of the six-week summer program, teachers worked on a number of nanoscience topics, such as the design of artificial biomembrane-mimicking systems for cell substrate applications; integrated wireless sensor systems; nano-batteries and characterization; and fabrication and testing 
of paper-based lithium ion batteries. Further, while engaging in their lab research, teachers participated in two graduatelevel courses. One course focused on STEM careers involving nanotechnology while the other focused on pedagogical methods, socially transformative STEM curricula, and nanotechnology module development. The RETAIN summer program culminated in a poster session where teachers' showcased their research methods and findings to the Indianapolis community. Additional details describing the RET program set-up can be found in Agarwal and colleagues' 2016 FIE publication [7].

As part of their course expectations, teachers were tasked to design and deploy hands-on, inquiry-based nanotechnology-centric teaching modules into their own teaching context, and to align modules with the Next Generation Science Standards (NGSS) [8] and Indiana State Standards [9]. In addition to the final poster presentations, during the last week of the summer program teachers' presented their modules to a cohort of teachers participating in a separate nanotechnology experience at IUPUI.

To explore the impact of the professional development program, this study proceeds in two parts. The first explores RETAIN teachers' outcomes resulting from the six-week experience and the second explores teachers' students' outcomes resulting from the teachers' module integration. Within the teacher section, we use descriptive statistics and comparative analyses to explore (i) teachers' satisfaction with the 2016 summer program, (ii) changes in teachers' nanotechnology perceptions, (iii) changes in teachers' nanotechnology content knowledge, and (iv) changes in teachers' STEM-specific epistemological beliefs. Within the student section, we report pre/post changes in teachers' students' (i) STEM attitudes and $21^{\text {st }}$ century learning skills and (ii) nanotechnology perceptions. The study closes with a comprehensive overview of these quantitative findings in light of teachers' weekly and post-summer written reflections, alongside our observations of teachers' module integration.

\section{RESUltS}

\section{A. RETAIN Teachers}

\section{1) Participant Overview}

During the summer of 2016, eight teachers visited the IUPUI campus to participate in a six-week immersive nanotechnology professional development program, RETAIN. Participants' racial backgrounds included White or Caucasian $(n=6)$, African American $(n=1)$, and Hispanic $(n=1)$. Five participants were male and three were female. Participants taught a variety of courses, including biology, chemistry, computer coding, earth and space science, and physics. One teacher taught at the middle school level, six at the high school level, and one at a community college. Five of eight participants estimated that $50 \%$ or more of their students were underrepresented minorities.

All eight teachers completed the 2016 summer program, including the associated pre/post summer evaluation metrics.
In addition, observations of three of the eight teachers' integration of nanotechnology content into their courses have taken place. These three teachers disseminated a pre/post survey to their students. These data are reported in the following sections.

\section{2) RETAIN Satisfaction}

Upon completion of the summer program, we asked teachers to express their satisfaction with the RETAIN summer experience. Specifically, eight Likert-type survey items were foregrounded with the script, "Please indicate to what extent you were satisfied with the RET experience in each of the following areas." Table I provides an overview of these results. These items were compiled into a single satisfaction score which showed good internal consistency $(\alpha=0.87)$ [10].

TABle I. Post-Program TeACHER SATISFACTION

\begin{tabular}{|c|c|c|}
\hline Item Description & $M$ & $S D$ \\
\hline $\begin{array}{l}\text { The opportunity to interact and discuss issues with other } \\
\text { employees at IUPUI }\end{array}$ & 3.50 & 0.53 \\
\hline $\begin{array}{l}\text { The availability and quality of resources, materials, and } \\
\text { equipment }\end{array}$ & 3.50 & 0.53 \\
\hline The opportunity to ask questions of the staff at IUPUI & 3.38 & 0.52 \\
\hline $\begin{array}{l}\text { The expertise and helpfulness of the RET management in } \\
\text { answering questions and problem solving }\end{array}$ & 3.25 & 0.46 \\
\hline Your relationship with your mentor & 3.25 & 0.89 \\
\hline The opportunity to participate as a member of a team & 3.25 & 0.71 \\
\hline $\begin{array}{l}\text { The materials and information you received before you } \\
\text { began the work experience }\end{array}$ & 3.00 & 0.53 \\
\hline $\begin{array}{l}\text { The orientation you received when you began the work } \\
\text { experience }\end{array}$ & 2.88 & 0.64 \\
\hline
\end{tabular}

Teachers were generally satisfied with the experience (the average response to the combined satisfaction construct was 3.25 out of 4). The component that teachers expressed the most satisfaction with was the opportunity to discuss issues with IUPUI employees $(M=3.50 ; S D=0.53)$ and the availability and quality of resources $(M=3.50 ; S D=0.53)$. Teachers were least satisfied with RETAIN orientation $(M=2.88 ; S D=0.64)$.

In addition to this post-program survey, throughout the program we disseminated weekly surveys to evaluate teachers' satisfaction with the associated research and course experiences. This data was used to formatively assess teacher satisfaction with and to iteratively improve the delivery of the program. Table II provides an overview of teachers' average weekly satisfaction with respect to the research experience and course experience. Note that all participants completed the survey nearly every week with the exceptions of week 2 where six participants completed the survey and week 4 where seven participants completed the survey. The numbers reported in Table II represent weekly averages. Participants responded to items on a 5-point Likert type scale where $1=$ Strongly Disagree and $5=$ Strongly Agree. As Table II indicates, teachers expressed moderate to strong satisfaction with both the research component $(M=4.09)$ and the course component $(M=4.25)$ of the RETAIN program. The two weeks with the highest research satisfaction were week $4(M=4.6)$ and week 1 $(M=4.5)$ and the weeks with the highest course satisfaction were week $3(M=4.3)$ and week $4(M=4.3)$. 
TABLE II.

WEEKLy TEACHER RESEARCH \& COURSE SATISFACTION

\begin{tabular}{|c|c|c|c|c|c|c|c|}
\hline Item Description & $M$ & $S D$ & W1 & W2 & W3 & W4 & W5 \\
\hline Research Satisfaction & 4.09 & - & 4.5 & 4.2 & 3.9 & 4.6 & 4.1 \\
\hline $\begin{array}{l}\text { Lab staff was/were } \\
\text { responsive to questions. }\end{array}$ & 4.47 & 0.34 & 4.9 & 4.5 & 4.1 & 4.7 & 4.1 \\
\hline $\begin{array}{l}\text { Lab staff was/were } \\
\text { knowledgeable. }\end{array}$ & 4.41 & 0.32 & 4.9 & 4.5 & 4.0 & 4.4 & 4.3 \\
\hline $\begin{array}{l}\text { This research will improve } \\
\text { some aspect of } \\
\text { instruction in my } \\
\text { classroom or school. }\end{array}$ & 4.34 & 0.29 & 4.5 & 4.5 & 3.9 & 4.6 & 4.3 \\
\hline $\begin{array}{l}\text { Lab work was } \\
\text { intellectually } \\
\text { stimulating. }\end{array}$ & 4.26 & 0.33 & 4.6 & 4.0 & 3.9 & 4.6 & 4.3 \\
\hline $\begin{array}{l}\text { Mentors were available is } \\
\text { needed. }\end{array}$ & 4.24 & 0.34 & 4.5 & 4.5 & 3.8 & 4.4 & 4.0 \\
\hline $\begin{array}{l}\text { Support was readily } \\
\text { available. }\end{array}$ & 4.23 & 0.31 & 4.1 & 4.3 & 3.9 & 4.7 & 4.1 \\
\hline $\begin{array}{l}\text { Research content was } \\
\text { useful to me. }\end{array}$ & 4.19 & 0.32 & 4.5 & 4.0 & 3.9 & 4.6 & 4.0 \\
\hline $\begin{array}{l}\text { This week's research was } \\
\text { productive. }\end{array}$ & 4.15 & 0.34 & 4.3 & 3.7 & 4.0 & 4.6 & 4.3 \\
\hline $\begin{array}{l}\text { Expectations were clearly } \\
\text { explained. }\end{array}$ & 3.95 & 0.38 & 4.0 & 3.7 & 3.6 & 4.6 & 3.9 \\
\hline Course Satisfaction & 4.25 & - & 4.1 & 4.0 & 4.3 & 4.3 & 3.7 \\
\hline $\begin{array}{l}\text { Course time was } \\
\text { appropriate. }\end{array}$ & 4.28 & 0.26 & 4.3 & 4.3 & 4.4 & 4.6 & 3.9 \\
\hline $\begin{array}{l}\text { Instructors were responsive } \\
\text { to questions. }\end{array}$ & 4.27 & 0.34 & 4.6 & 4.2 & 4.5 & 4.3 & 3.8 \\
\hline $\begin{array}{l}\text { Instructors were } \\
\text { knowledgeable. }\end{array}$ & 4.24 & 0.34 & 4.5 & 4.0 & 4.5 & 4.4 & 3.8 \\
\hline $\begin{array}{l}\text { Course content was clearly } \\
\text { presented. }\end{array}$ & 4.14 & 0.22 & 4.1 & 4.0 & 4.3 & 4.4 & 3.9 \\
\hline $\begin{array}{l}\text { Course content will } \\
\text { improve some aspect of } \\
\text { instruction in my } \\
\text { classroom. }\end{array}$ & 4.03 & 0.19 & 4.0 & 4.0 & 4.3 & 4.1 & 3.8 \\
\hline $\begin{array}{l}\text { Overall these course } \\
\text { meetings were effective. }\end{array}$ & 4.02 & 0.29 & 4.1 & 3.8 & 4.3 & 4.3 & 3.6 \\
\hline $\begin{array}{l}\text { Course content will be } \\
\text { useful to me. }\end{array}$ & 4.01 & 0.24 & 4.1 & 4.0 & 4.0 & 4.3 & 3.6 \\
\hline $\begin{array}{l}\text { Course meetings } \\
\text { stimulated my interest. }\end{array}$ & 3.97 & 0.35 & 3.8 & 4.3 & 4.0 & 4.3 & 3.5 \\
\hline $\begin{array}{l}\text { Course materials were } \\
\text { helpful. }\end{array}$ & 3.85 & 0.37 & 3.8 & 3.3 & 4.1 & 4.3 & 3.8 \\
\hline
\end{tabular}

Note: 1 = Strongly Disagree; 2 = Disagree $; 3=$ Undecided $; 4=$ Agree; 5 = Strongly Agree

\section{3) Nanotechnology Self-Report Data}

This section explores the research question, "To what extent did the RETAIN program influence participants' understanding and perceptions of nanotechnology?" The section provides data elucidating (i) pre/post changes in teachers' self-reported perceptions, (ii) pre/post changes in teachers' scores on a nanotechnology content test, and (iii) changes in teachers' self-reported epistemological beliefs.

We used the Nanotechnology Careers \& Perceptions Survey [6] to explore the impact of the RETAIN program on teachers' self-reported nanotechnology career knowledge and their perceptions of the potential of nanotechnology for advancing societal needs. This survey contains two constructs, each of which showed acceptable to excellent internal consistency reliability [10] when analyzing the stacked pre/post teacher data (see Table III).

Table III. Teacher Nanotechnology Careers \& Perceptions Results

\begin{tabular}{|c|c|c|c|c|}
\hline \multirow{2}{*}{$\begin{array}{l}\text { Construct ( } \boldsymbol{\alpha}) \\
\text { and Construct items }\end{array}$} & \multicolumn{2}{|c|}{ Pre } & \multicolumn{2}{|c|}{ Post } \\
\hline & $M$ & $S D$ & $M$ & $S D$ \\
\hline Nano-Careers $(\alpha=0.95)^{*}$ & 2.44 & 0.98 & 4.03 & 0.41 \\
\hline $\begin{array}{l}\text { I understand the career opportunities in } \\
\text { nanotechnology. }\end{array}$ & 2.63 & 1.03 & 4.25 & 0.46 \\
\hline $\begin{array}{l}\text { I am knowledgeable about various } \\
\text { nanotechnology majors available to } \\
\text { students. }\end{array}$ & 2.63 & 1.19 & 4.13 & 0.35 \\
\hline $\begin{array}{l}\text { I am aware of opportunities for majoring in } \\
\text { nanotechnology at [the university]. }\end{array}$ & 2.38 & 1.06 & 3.88 & 0.64 \\
\hline $\begin{array}{l}\text { I am knowledgeable concerning the } \\
\text { requirements for admission to a } \\
\text { nanotechnology program. }\end{array}$ & 2.13 & 0.64 & 3.88 & 0.83 \\
\hline Nano-Potential $(\alpha=0.74)$ & 3.84 & 0.58 & 4.00 & $\mathbf{0 . 5 0}$ \\
\hline Nanotechnologists are innovative. & 4.38 & 0.74 & 4.38 & 0.52 \\
\hline $\begin{array}{l}\text { I like the scope and variety of work that is } \\
\text { conducted using nanotechnology. }\end{array}$ & 4.00 & 0.93 & 4.38 & 0.52 \\
\hline $\begin{array}{l}\text { Nanotechnology plays an important role in } \\
\text { solving society's problems. }\end{array}$ & 3.50 & 0.53 & 3.63 & 0.74 \\
\hline $\begin{array}{l}\text { Nanotechnology has contributed greatly to } \\
\text { fixing problems in the world. }\end{array}$ & 3.50 & 0.93 & 3.63 & 0.74 \\
\hline
\end{tabular}

As the data was approximately non-normal, a series of Wilcoxon Signed Ranks tests [11] were used to explore the impact of the RETAIN program on teachers' responses to the Nano-Careers and Nano-Potential survey constructs. These results indicated that teachers' responses to the Nano-Careers construct significantly improved $(z=-2.527, \mathrm{p}<.05)$. In contrast, changes in teacher responses to the Nano-Potential construct were not found to be significant $(z=-1.237)$.

\section{4) Nanotechnology Content Knowledge}

Teachers completed a nanotechnology content test before and after the summer RETAIN experience. This test included eight categories, each with a series of underlying questions. A perfect response would receive a mark of 28. Questions prompted participants to identify nanoscale objects (e.g., carbon nanotube, quantum dots, DNA), to define what makes an object a "nanoscale" object (e.g., its being 1 to 100 nanometers in size), to identify properties that may be distinct between nanoscale and micro- or macro-scale objects, etc. All participants completed the content test pre and post course. The average score pre-course was $11.75(S D=3.58$; $\min =6$; $\max =17)$. The average course post-course was $17.35(S D=$ 3.02; $\min =13 ; \max =22$ ).

Due to the small sample size, a Wilcoxon Signed Ranks test [11] was used to explore the impact of the RETAIN program on teachers' nanotechnology content knowledge. These results indicated that teachers' nanotechnology content knowledge significantly improved as a result of the RETAIN program $(z=-2.524, \mathrm{p}<.05)$.

\section{5) Epistemological Beliefs of STEM}

Next, we used the Epistemological Beliefs Questionnaire [12] to elucidate to what extent the program impacted teachers' 
personal epistemological beliefs regarding the attainment of objective truths in STEM. This instrument contains four constructs. After compiling and stacking all pre/post responses, the internal consistency reliability for two of the constructs was acceptable (Certainty, $\alpha=0.745$; Attainment of Truth, $\alpha=$ $0.799)$ whereas two were unacceptable (Justification: Personal, $\alpha=0.121$; Source: Authority, $\alpha=0.577$ ) [10]. Table IV shows the pre and post teacher responses to the two reliable constructs from the Epistemological Beliefs Questionnaire.

TABle IV. Teacher Epistemological Beliefs Questionnaire Results

\begin{tabular}{|c|c|c|c|c|}
\hline \multirow{2}{*}{$\begin{array}{c}\text { Construct ( } \boldsymbol{\alpha}) \\
\text { and Construct items }\end{array}$} & \multicolumn{2}{|c|}{ Pre } & \multicolumn{2}{|c|}{ Post } \\
\hline & Avg & $S D$ & Avg & $S D$ \\
\hline Certainty $(\alpha=0.75)^{*}$ & 1.97 & 0.70 & 1.61 & 0.43 \\
\hline $\begin{array}{l}\text { Most of what can be known in this subject } \\
\text { is already known. }\end{array}$ & 2.38 & 1.51 & 1.63 & 1.06 \\
\hline Principles in this field are unchanging. & 2.25 & 1.16 & 1.38 & 0.74 \\
\hline $\begin{array}{l}\text { Answers to questions in this field change } \\
\text { as experts gather more information. (-) }\end{array}$ & 1.63 & 1.06 & 4.50 & 0.53 \\
\hline $\begin{array}{l}\text { All professors in this field would probably } \\
\text { come up with the same answer to } \\
\text { questions in this field. }\end{array}$ & 2.13 & 1.36 & 1.50 & 0.53 \\
\hline $\begin{array}{l}\text { In this subject, most work has only one } \\
\text { right answer. }\end{array}$ & 1.63 & 0.52 & 1.88 & 0.83 \\
\hline $\begin{array}{l}\text { In this subject, it is good to question the } \\
\text { ideas presented. (-) }\end{array}$ & 1.88 & 1.13 & 1.50 & 0.53 \\
\hline Truth is unchanging in this subject. & 2.13 & 1.55 & 1.63 & 0.74 \\
\hline $\begin{array}{l}\text { All experts in this field understand the } \\
\text { field in the same way. }\end{array}$ & 1.75 & 0.46 & 1.75 & 1.04 \\
\hline Attainment of Truth $(\alpha=.80)$ & 3.25 & 0.93 & 2.94 & 1.02 \\
\hline $\begin{array}{l}\text { Experts in this field can ultimately get to } \\
\text { the truth. }\end{array}$ & 3.25 & 1.04 & 3.00 & 1.07 \\
\hline $\begin{array}{l}\text { If scholars try hard enough, they can find } \\
\text { the answers to almost anything. }\end{array}$ & 3.25 & 1.04 & 2.88 & 1.13 \\
\hline
\end{tabular}

As the data was approximately non-normal, a series of Wilcoxon Signed Ranks tests [11] were used to explore the impact of the program on teachers' epistemological beliefs pertaining to Certainty and Attainment of Truth constructs. These results indicated that teachers' responses to the Certainty construct significantly changed as a result of their participation in the RETAIN program $(z=1.980, \mathrm{p}<.05)$. The teachers' responses to the Attainment of Truth construct were not significantly different before and after the program $(z=1.167)$.

\section{B. RETAIN Students}

\section{1) Participant Overview}

Three teachers integrated the modules they developed during the summer within their classrooms. One teacher taught biology at the high school level (which is a required course), a second taught earth sciences at the high school level (which is an elective course), and the third taught a middle school science course. 341 students completed at least part of the presurvey and 272 students completed at least part of the postsurvey. Largely due to inconsistencies in students' reporting of their anonymous identifier, we only connected 166 pre and post responses (see Table V). Specifically, many students either did not fill in all requested details or they reported what appeared to be their student ID either pre or post, and in their alternate survey response they reported the identifier as requested in the prompt (the prompt asked students to write the first letter of their first name, the first letter of their last name, and then their 8 digit date of birth as MMDDYYYY).

TABLE V. OVERVIEW OF STUDENT RESPONDENTS

\begin{tabular}{lccc}
\hline Teacher Identifier & Pre & Post & Combined \\
\hline $2016-04$ & 135 & 135 & 117 \\
$2016-07$ & 113 & 72 & 44 \\
$2016-09$ & 93 & 65 & 5 \\
\hline Total & $\mathbf{3 4 1}$ & $\mathbf{2 7 2}$ & $\mathbf{1 6 6}$ \\
\hline
\end{tabular}

\section{2) STEM Attitudes}

This section explores the research question, "To what extent do the students of RET participants demonstrate improved attitudes towards STEM after experiencing a nanolesson or series of lessons?" To evaluate this question, we utilized the S-STEM survey [13], an instrument designed to gauge the disciplinary interests and $21^{\text {st }}$ century learning skills of K-12 students through a series of self-report questions. Four S-STEM constructs include (i) math attitudes, which includes interests in math and confidence in working through math problems, (ii) science attitudes, (iii) engineering and technology attitudes, and (iv) $21^{\text {st }}$ century learning attitudes, or perceptions of their ability to work effectively in teams and to succeed in various tasks. Student responses were collected on a 5-point Likert-type scale where 1 = "Strongly Disagree" and 5 $=$ "Strongly Agree". In order to determine changes in the student responses to the S-STEM constructs, and after reversing the negatively worded items, we computed the internal consistency reliability for each scale by using stacked pre and post data. Each construct showed good to excellent internal consistency reliability $(\alpha$ Math $=.91, \alpha$ science $=.87$, $\alpha$ Engineringr/Technology $=.86$, and $\alpha_{21 \text { st century skills }}=.92$ ). An overview of students' pre and post responses is shown in Table VI.

TABLE VI. STUDENT S-STEM RESUlTS

\begin{tabular}{lccccccccc}
\hline \multirow{2}{*}{ Construct } & \multicolumn{4}{c}{ Pre } & \multicolumn{4}{c}{ Post } & \multicolumn{4}{c}{ Difference Scores } \\
\cline { 2 - 10 } & $\boldsymbol{n}$ & $\boldsymbol{M}$ & $\boldsymbol{S D}$ & $\boldsymbol{M}$ & $\boldsymbol{S D}$ & $\boldsymbol{M}$ & $\boldsymbol{S D}$ & $\boldsymbol{t}$ & $\boldsymbol{d}$ \\
\hline $21^{\text {st }}$ Century & 156 & 4.10 & .55 & 3.99 & .69 & -.10 & .68 & 1.82 & .16 \\
Engr/Tech & 156 & 3.41 & .66 & 3.29 & .68 & -.12 & .53 & $2.83^{*}$ & .18 \\
Mathematics & 161 & 3.05 & .93 & 3.07 & .89 & .02 & .47 & 0.48 & .02 \\
Science & 161 & 2.99 & .66 & 2.94 & .67 & -.05 & .54 & 1.10 & .07 \\
\hline$*=\mathrm{p}<.05 ;$ Note: 1 1 $=$ Strongly Disagree; $2=$ Disagree; 3 $=$ Undecided; $4=$ \\
Agree $;=$ Strongly Agree
\end{tabular}

A series of paired sample t-tests were conducted to explore changes in student responses to the S-STEM constructs. There was a significant change in student responses to the Engineering and Technology construct from pre $(M=3.41, S D$ $=0.66)$ to post $(M=3.29, S D=.68), t(161)=2.83, \mathrm{p}<.05$ (two-tailed) with an average decrease of 0.12 . Notably, the effect size $(d=.18)$ was below Cohen's threshold denoting a small effect size [14]. No other significant changes were found.

\section{3) Nanotechnology Self-Report Data}

Next, we used the Nanotechnology Careers \& Perceptions Survey [6] (the same survey describe above) to explore the impact of module integration on students' self-reported nanotechnology career knowledge and their perceptions of the 
potential of nanotechnology for advancing societal needs. The two constructs showed good to excellent internal consistency reliability [10] when analyzing the stacked pre/post participant data (see Table VII).

TABLE VII. STUdent Nanotechnology CaReERS \& PeRCEPTIONS Results

\begin{tabular}{|c|c|c|c|c|}
\hline \multirow{2}{*}{$\begin{array}{l}\text { Construct ( } \boldsymbol{\alpha}) \\
\text { and Construct items }\end{array}$} & \multicolumn{2}{|c|}{ Pre } & \multicolumn{2}{|c|}{ Post } \\
\hline & $M$ & $S D$ & $M$ & $S D$ \\
\hline Nano-Careers $(\alpha=0.90 ; n=134)$ & 2.32 & .92 & 2.83 & .89 \\
\hline $\begin{array}{l}\text { I understand the career opportunities in } \\
\text { nanotechnology }\end{array}$ & 2.41 & 1.00 & 2.94 & 1.09 \\
\hline $\begin{array}{l}\text { I am aware of opportunities for majoring in } \\
\text { nanotechnology at IUPUI. }\end{array}$ & 2.38 & 1.04 & 2.85 & 1.08 \\
\hline $\begin{array}{l}\text { I am knowledgeable about various } \\
\text { nanotechnology majors available to } \\
\text { students. }\end{array}$ & 2.36 & .97 & 2.77 & 1.05 \\
\hline $\begin{array}{l}\text { I am knowledgeable concerning the } \\
\text { requirements for admission to a } \\
\text { nanotechnology program. }\end{array}$ & 2.28 & .93 & 2.61 & .98 \\
\hline Nano-Potential $(\alpha=0.87 ; n=131)$ & 3.15 & .78 & 3.32 & .77 \\
\hline Nanotechnologists are innovative. & 3.11 & .88 & 3.43 & .93 \\
\hline $\begin{array}{l}\text { Nanotechnology plays an important role in } \\
\text { solving society's problems. }\end{array}$ & 3.19 & .88 & 3.38 & .84 \\
\hline $\begin{array}{l}\text { Nanotechnology has contributed greatly to } \\
\text { fixing problems in the world. }\end{array}$ & 3.25 & .92 & 3.37 & .97 \\
\hline $\begin{array}{l}\text { I like the scope and variety of work that is } \\
\text { conducted using nanotechnology. }\end{array}$ & 3.02 & .89 & 3.12 & .88 \\
\hline
\end{tabular}

A series of paired sample t-tests were conducted to explore changes in student responses to the nanotechnology constructs. There was a significant change in student responses to the Nano-Careers construct from pre $(M=2.32$, $S D=0.88)$ to post $(M=3.31, S D=.76), t(134)=10.49, \mathrm{p}<$ .05 (two-tailed) with a 1.00 average increase. Using Cohen's criterion, this corresponded with a large effect size $(d=1.20)$ [14]. Likewise, there was a significant change in student responses to the Nano-Potential construct from pre $(M=3.15$, $S D=0.87)$ to post $(M=3.32, S D=.77), t(131)=6.40, \mathrm{p}<$ .05 (two-tailed) with a 0.16 average increase. Using Cohen's criterion, this indicated a small effect size $(d=0.21)[14]$.

\section{SUMMARY}

This second year of implementation of the RETAIN program revealed many positive results as well as a few surprising insights. In the following sections, we describe first the teacher results and second the student results. Along with the quantitative data reported throughout this paper, we use open-ended responses collected as part of the weekly surveys or at the end of the summer program alongside observational data to consider potential causes of the quantitative findings.

\section{A. Teacher Results}

Overall, teachers expressed moderate to great satisfaction with the 2016 RETAIN program. Teachers were least satisfied with the pre-program components and orientation, although even these results were slightly positive. Teachers expressed the most satisfaction with the week 1 and week 4 research components. In order to understand these results, we revisited teachers' written responses that were collected during the weekly reflection prompts.
Upon inspection of teachers' week 1 reflections, teachers tended to describe the first week as a process of becoming acquainted with their mentors, lab expectations, and their research responsibilities. This corresponded with what we might describe as a novelty factor. Hence, while teachers described challenges in this first week, these factors did not appear detrimental to their overall satisfaction. As an example, one teacher stated in their weekly reflection, "Of course, the learning curve is quite steep at the moment. Learning the procedures, developing acceptable lab techniques, being introduced to new software, and learning the calculations needed to move forward can be quite humbling." Another teacher described the first week as one of grasping for meaning and directionality, stating, "Currently, it appears that my purpose in the lab is to learn techniques and compare methodologies for my project..." (Italics added).

The magnitude of teachers' satisfaction with the research experience slightly reduced (although the average responses remained positive) from week 1 to weeks 2 and 3 . It then increased again in week 4 . A closer inspection of the response items (see Table II) suggests that teachers felt more productivity coupled with more support from their mentors and the program staff during this week when compared to other weeks. To further understand this finding, we explored teachers' week 4 reflections. These responses indicated that productivity was a key factor in their week 4 satisfaction, as they were actively translating their research experiences into tangible outcomes. For example, teachers were well into the data collection process and were actively using nanotechnology to address their research questions. Further, teachers were beginning to translate their research experiences into final deliverables (e.g., a poster presentation, curricular modules).

Lastly, week 5 showed the lowest (albeit, still slightly positive) teacher satisfaction with respect to the course component. Interestingly, much of the class time during this week was allocated as work time for teachers to finalize their curricular modules and their research posters. An inspection of teachers' written responses indicated that they appreciated this time. As one teacher wrote, "Time was allotted for groups to work together on group projects. This is greatly appreciated." A closer inspection of the survey items indicates that perhaps while teachers were appreciative of the time to actively work on their final deliverables, teachers simultaneously felt that they received less new knowledge from the courses in week 5.

In addition to teacher satisfaction, we explored changes in teachers' self-reported nanotechnology perceptions. This component indicated that teachers' knowledge of nanotechnology-related careers greatly enhanced during the program, but their perceptions of nanotechnology did not significantly increase. The changes in teacher responses to the Nanotechnology constructs directly correspond with those from the year 1 cohort [6]. Interestingly, while the year 2 teachers' post-program responses to the Nano-Careers construct $(M=4.03, S D=.41)$ were higher than the year 1 
cohort's $(M=3.90, S D=.29)$, their post-program responses to the Nano-Potential construct were identical $(M=4.00)$.

This was our first implementation of the nanotechnology content test with RETAIN teachers. The pre/post analyses indicated that teachers' content knowledge significantly increased. Upon inspection of teachers' post-RETAIN scores, the concepts that teachers struggled with the most included (i) articulating the steps of basic photolithography (only one student answered this correctly in the post-test), (ii) describing how to increase the resolution of a scanning microscope (three answered correctly), and (iii) graphing quantum dot behavior (no teacher answered this question completely accurately). Approximately half of the teachers also responded incorrectly to solar cell and microfluidics questions. In the future, a focus on these conceptual components will be integrated into the program more intentionally.

Finally, we administered the Epistemological Beliefs Questionnaire [12] pre and post course. An analysis of responses to the Certainty construct indicated that teachers' became less certain of the unchanging nature of "truth" in STEM. This finding was not altogether surprising. Materials often behave differently or exhibit different properties at the nanoscale when compared to the micro or macro scale. The rapid advancement of nanotechnology research and development has led to a more frequent realization of scientific revolutions where "the rules of normal science become increasingly blurred" [15]. Teachers' exposure to nanotechnology research, especially concepts that challenge textbook problems that teachers may have included within their courses prior to RETAIN, may contribute to teachers' awareness of the oft-changing fundamental principles in STEM.

\section{B. Student Results}

In addition to analyzing teacher outcomes, we investigated how teachers' integration of nanotechnology into their classrooms influenced their students. These analyses revealed a few surprising insights. To help explain these findings, we rely on classroom observations, although we caution that this data has not been systematically explored and, hence, many of these explanations are largely conjectural.

Using the S-STEM survey, we found that students' Engineering and Technology attitudes decreased. Yet, STEM integration, with a focus on engineering [16], was one of the primary objectives of the curricular module development. Notably, what the three teachers integrated into their classrooms tended to resemble a subset of the module they developed over the summer. We would surmise that this is due to the curricular content that teachers are expected to integrate into their courses. Nanotechnology is not an explicit component of the Indiana state standards, so teachers tend to be resistive to integrating more than one or a few lessons into their classrooms. Hence, what students engaged with in classrooms was not a holistic scientific process, nor did it reflect engineering design in a comprehensive sense. Rather, teachers tended to hold a pre-lab to establish students' general understanding of nanotechnology as a concept, often focusing on scale and/or material properties. Next, teachers had students observe material behavior within a lab setting (one teacher focused on fuel cells; another on sunscreen; and a third on measurement). Lastly, teachers prompted students to translate their observations into a conceptual understanding of nanoscale properties. Hence, the student data largely represents a few of days of exposure to nanotechnology concepts.

Nonetheless, student self-report data to the Nano-Potential and Nano-Careers scales showed significant increases on both of these constructs. This finding focuses more on knowledge generation and nanotechnology perceptions rather than generalized STEM attitudes or interests, so we feel this finding is not altogether contradictory with the results from the S-STEM. As a potential cause of this finding, one teacher showed a series of videos exhibiting nanotechnology's unique properties. One video showed a phone that was first coated with nanomaterials and then the individual in the video proceeded to hit the phone with a hammer. The hammer's impact left no trace of damage to the phone whatsoever. Likewise, another teacher's modules focused on fuel cells, but the lesson questions prompted students to consider the environmental implications of nonrenewable resources (like coal, relied heavily upon in Indiana) and the potential for fuel cells in offsetting the negative effects of coal use.

In the future, as more teachers integrate nanotechnology modules into their classrooms, we hope to analyze the potential moderating effects of the module and teacher factors on student outcomes. For example, we would like to explore what content appears most engaging to students, how the duration of exposure to nanotechnology lessons influences their perceptions, as well as how their STEM interests impact their nanotechnology attitudes. Further, many of the teacherlevel variables may impact student outcomes, such as teachers' perceptions of nanotechnology or satisfaction with the summer experience.

\section{ACKNOWLEDGMENT}

This material is based upon work supported by the National Science Foundation Research Experiences for Teachers Program under Grant No. 1406995. Any opinions, findings, and conclusions or recommendations expressed in this material are those of the authors and do not necessarily reflect the views of the National Science Foundation.

We would also like to thank the teachers who participated in each of these evaluation measures, especially the teachers who integrated their modules into their classrooms. Further, we would like to thank all the mentors and staff that supported the RETAIN summer program. Without all of you, this study would not have been possible. 


\section{REFERENCES}

[1] nano.gov. "NNI Supplement to the President's FY 2001 Budget," Retrieved March 9, 2017; https://www.nano.gov/node/1075.

[2] Subcommittee on Nanoscale Science Engineering and Technology, "The National Nanotechnology Initative: Supplement to the President's 2017 Budget," National Science and Technology Council, Washington, DC, 2016.

[3] NSET, "National Nanotechnology Initiative Strategic Plan," Washington, D.C., 2014.

[4] "The Energy Issue," nanooze, no. 14, 2015.

[5] nano.gov. "For K-12 Students," Retrieved March 9, 2017; https://www.nano.gov/education-training/k12.

[6] J. L. Hess, C. Feldhaus, M. Agarwal, and M. Rizkalla, "An Initial Investigation on the Impact of a Research Experience Traineeship Program for Integrating Nanotechnology into Pre-College Curriculum," in American Society for Engineering Education Annual Conference, Columbus, OH, 2017.

[7] M. Agarwal, B. H. Sorge, G. A. Fore, D. Minner, C. Feldhaus, and M. Rizkalla, "Research Models with Dissemination Activities for Research Experiences for Teachers (RET)," in Frontiers in Education Annual Conference, Erie, PA, 2016.
[8] NGSS Lead States, Next Generation Science Standards: For States, By States, Washington, DC: The National Academies Press, 2013.

[9] Indiana Department of Education. "Science \& Computer Science," Retrieved January 26, 2017; http://www.doe.in.gov/standards/sciencecomputer-science.

[10] R. F. DeVellis, Scale development: Theory and Applications, Los Angeles, CA: SAGE Publications, Inc., 2011.

[11] F. Wilcoxon, "Individual Comparisons by Ranking Methods," in Biometrics Bulletin, vol. 1, no. 6, 1945, pp. 80-83.

[12] B. K. Hofer, "Dimensionality and Disciplinary Differences in Personal Epistemology," in Contemporary Educational Psychology, vol. 25, 2000, pp. 374-405.

[13] M. Faber, and A. Unfried, "Student Attitudes toward STEM: The Development of Upper Elementary School and Middle/High School Student Surveys," in American Society for Engineering Education Annual Conference, Atlanta, GA, 2013.

[14] J. Cohen, "A Power Primer," in Quantitative Methods in Psychology, vol. 112, no. 1, 1992, pp. 155-159.

[15] T. S. Kuhn, The structure of scientific revolutions, 3rd ed., Chicago, IL: The University of Chicago Press, 1996.

[16] M. J. Nathan, R. Srisurichan, C. Walkington, M. Wolfgram, C. Williams, and M. W. Alibali, "Building Cohesion across Representations: A Mechanism for STEM Integration," in Journal of Engineering Education, vol. 102, no. 1, 2013, pp. 77-116. 